\title{
Tree Stands and Liana Community in Royal Belum State Park, Malaysia
}

\author{
ZAKARIA RAHMAD $^{1,2}$, SYAFIQ JOHARI ${ }^{1}$ \& GBENGA FESTUS AKOMOLAFE ${ }^{* 1,3}$ \\ ${ }^{1}$ School of Biological Sciences, Universiti Sains Malaysia, 11800, Gelugor, Pulau Pinang, Malaysia; \\ ${ }^{2}$ Center for Global Sustainability Studies (CGSS), Level 5, Hamzah Sendut Library 1, Universiti Sains \\ Malaysia, 11800, Pulau Pinang, Malaysia; ${ }^{3}$ Department of Botany, Federal University Lafia, P.M.B. \\ 146, Lafia, Nasarawa State, Nigeria \\ *Corresponding author: gfakomolafe@yahoo.com \\ Received: 24 September 2018 \\ Accepted: 27 November 2018 \\ Published: 30 December 2018
}

\begin{abstract}
The diversity of lianas and trees were studied in five study sites of 100 x 20 m within the Royal Belum State Park, Malaysia with a view to provide baseline information on their incidence, taxonomy and ecological distributions. The sites include Sungai Kejar, Sungai Papan, Sungai Papan 2, Teluk Gopal and Sungai Kooi with at least 1000 $\mathrm{m}$ apart. These plots were further sub-divided into five sub-plots of $20 \times 20 \mathrm{~m}$ each. Lianas with a diameter at breast height $(\mathrm{dbh}) \geq 1 \mathrm{~cm}$ and trees with $\mathrm{dbh} \geq 10 \mathrm{~cm}$ were identified and frequencies of occurrence were determined. Lianas comprising 92 species from 23 families while trees comprising 221 species and 48 families were enumerated. Annonaceae was the richest family of lianas and trees (19 species and 23 species respectively). Connarus (Connaraceae) and Spatholobus (Fabaceae) had the highest number of lianas (six species) whilst Syzygium (Myrtaceae) had the highest number of trees (11 species). There are significant differences in all the diversity indices among the study sites, except between Sungai Papan and Teluk Gopal which were the richest and most diverse in liana species. These two sites also showed high similarity index in liana species $(0.50)$ followed by Sungai Kejar and Sungai Papan 2 (0.37). Sungai Kejar was however observed to have the highest tree species richness. These study sites could be described as very rich with a high diversity of lianas and trees. Although, it is richer in trees than lianas which means that the level of disturbance of the park is very low.
\end{abstract}

Keywords: Annonaceae, Connarus, forests, lianas diversity, Perak, Syzygium

Copyright: This is an open access article distributed under the terms of the CC-BY-NC-SA (Creative Commons Attribution-NonCommercial-ShareAlike 4.0 International License) which permits unrestricted use, distribution, and reproduction in any medium, for non-commercial purposes, provided the original work of the author(s) is properly cited.

\section{INTRODUCTION}

Tropical forests are important carbon pools, comprising approximately $40 \%$ of terrestrial carbon storage (Dixon et al., 1994). None of that matters because deforestation still going rampant and the quality of habitable spaces turned plummet (Potter, 1999). Wildlife creatures especially, are threatened by the scenario and have always been in great jeopardy. The intact forest, Royal Belum State Park, is recognizable for the pristine jungle, hosting innumerable floras and faunas. The excessive beauty of the forest gives protection to wild animals like tigers, elephants etc. (Khairil et al., 2012). Moreover, a sparse canopy covers wholly shade everything beneath as promoting a nature of complexity and essential for wildlife interaction.

Lianas are woody climber species that are very abundant in tropical forests forming about $45 \%$ of the total woody plants population in such forests (Addo-Fordjour et al., 2008; Schnitzer \& Bongers, 2011). Liana and tree exhibit mutual relationship, in which liana benefiting more than its counterpart. This invariably means that lianas are trees competitors which disrupt their regeneration processes (Tobin et al., 2012). Over the decades, the studies on trees are ubiquitous and researchers mainly pinpointed tree behavior in terms of ecology, functions and benefits. On the contrary, the ecology of lianas and their distribution in tropical forests are scantily perceived and became a lesser known subject amongst researchers (Addo-Fordjour et al., 2016). Unknowingly, lianas are branded as a plant habit that only contribute nuisance to the forest ecosystem. Though they are very useful in the proper functioning of tropical ecosystems, their abundance in such forests is disastrous to native trees (Schnitzer et al., 2000; Pérezsalicrup, 2001; Ingwell et al., 2010; Putz, 2012). The misconception, however, weighed our team 
to uplift the information on the occurrence of lianas alongside trees and to list important and endangered species in Royal Belum State Park. This will provide an inventory of species that will be useful for future researchers.

\section{MATERIALS AND METHODS}

\section{Study Site}

This study was carried out at the Royal Belum State Park, Perak, Malaysia (Figure 1). This is a UNESCO World heritage site covering an area of 117,500 ha and straddling the northern, undisturbed and pristine lowland dipterocarp, hill dipterocarp and lower montane forests (up to about $1,533 \mathrm{~m}$ above sea level) of northern Peninsular Malaysia. This forms the northern and strategic component of the Central Forest Spine (CFS). It is considered as one of the oldest protected park that is undisturbed in Peninsular Malaysia. This park has been referred to as the biodiversity hotspot in Malaysia hosting diverse ecosystems and habitats for several flora and fauna species in which many of them are endemic, rare, vulnerable or otherwise threatened in Malaysia and the region.

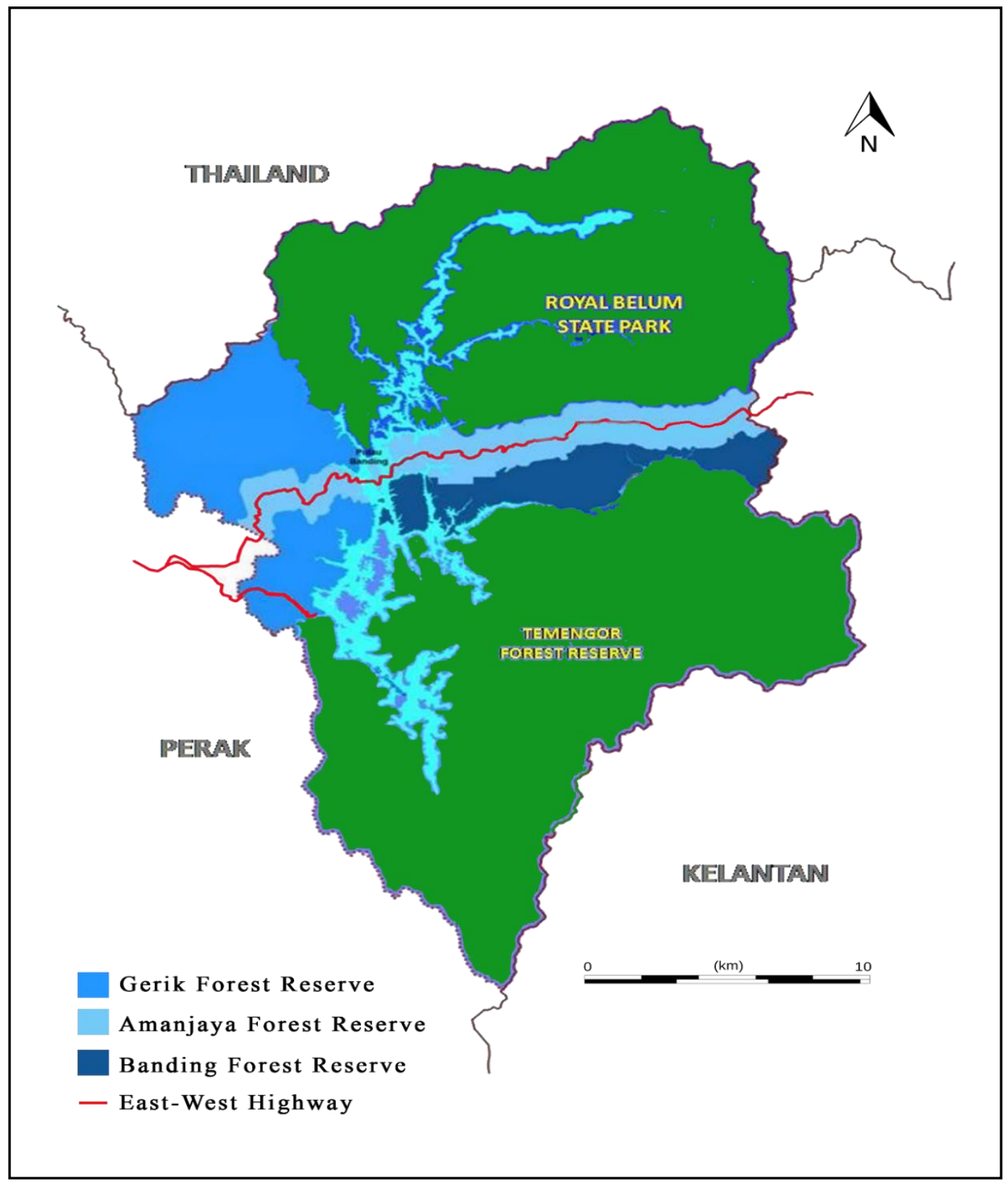

Figure 1. The map of Belum-Temengor Forest Complex (Redrawn from: https://mnshornbillvolunteerprogramme.wordpress.com/about/). 


\section{Sampling Procedure}

The occurrence of liana and trees were enumerated in five study sites within the park, namely; Sungai Kejar, Sungai Papan, Sungai Papan 2, Teluk Gopal and Sungai Kooi (Table 1). For each site, plots were randomly established with the size of $100 \times 20 \mathrm{~m}$ (0.2 ha). Subsequently, these plots were further divided into five subplots $(20 \mathrm{~m} \times 20 \mathrm{~m})$. Within the subplots, lianas with $\mathrm{dbh} \geq 1 \mathrm{~cm}$ and trees with $\mathrm{dbh} \geq 10 \mathrm{~cm}$ were identified. All processed specimens were kept in the Herbarium of Universiti Sains Malaysia, Pulau Pinang for further reference. Unidentified species were recorded by physical appearances such as leaf, flowers and fruits for further recognition by referring to the books and forest manual provided (Ng, 1978, 1989; Whitmore,1983a,b; Kiew et al., 2010, 2011, 2012).

Table 1. Geographical coordinate of sampling sites.

\begin{tabular}{cccc}
\hline Location & Latitude $(\mathrm{N})$ & Longitude $(\mathrm{E})$ & Elevation $(\mathrm{m})$ \\
\hline Sungai Kooi & $05^{\circ} 37^{\prime} 40.6^{\prime \prime}$ & $101^{\circ} 26^{\prime} 40.8^{\prime \prime}$ & 540 \\
Sungai Papan & $05^{\circ} 37^{\prime} 40.6^{\prime \prime}$ & $101^{\circ} 24^{\prime} 10.3^{\prime \prime}$ & 290 \\
Sungai Papan 2 & $05^{\circ} 37^{\prime} 23.8^{\prime \prime}$ & $101^{\circ} 24^{\prime} 39.0^{\prime \prime}$ & 405 \\
Sungai Kejar & $05^{\circ} 48^{\prime} 06.2^{\prime \prime}$ & $101^{\circ} 25^{\prime} 33.4^{\prime \prime}$ & 514 \\
Teluk Gopal & $05^{\circ} 36^{\prime} 37.7^{\prime \prime}$ & $101^{\circ} 23^{\prime} 28.4^{\prime \prime}$ & 360 \\
\hline
\end{tabular}

\section{Statistical Analysis}

The lianas and trees diversity indices such as Shannon index, Simpson index and Evenness index were quantified for each study site using PAST software (Rahmad \& Akomolafe, 2018). Incidence-based rarefaction-extrapolation analysis, which is a non-asymptotic species richness evaluator, was carried out to estimate the species richness of lianas and trees species in the study sites using the twenty-five sample size.

A significant difference in species richness between the study sites was determined using confidence intervals, constructed by 100 bootstrap replicates (Addo-Fordjour et al., 2016). Software called iNEXT (online version) was used for this (Chao et al., 2016). If the confidence intervals of the curves do not overlap, estimates of species richness are regarded as significantly different. However, if the confidence intervals of the curves overlap, then the estimates of species richness are not significantly different.

Analysis of similarity is a non-dependent analysis of the sample size as the indication of the presence/absence data for species in a community are particularly used (Krebs, 1989). Range of similarity commences from 0.0 (least similar) to 1.0 (highly similar). Modified Morisita's Similarity was preferably used due to its independence on the sample size. Hence, the unweighted pair-group method using arithmetic averages (UPGMA) was performed as the clustering method (Romesburg, 1984). Multivariate Statistical Package (MVSP) version 3.22, Kovach Computing Services coordinated the analysis.

\section{RESULTS}

\section{Diversity, Richness and Similarities of Liana Species Among Study Sites}

In all study sites, 92 species of lianas belonging to 23 families were identified (S1). The largest liana family was Annonaceae (19 species) followed by Connaraceae (11 species) and Fabaceae (11 species). Annonaceae, which was the largest family, was composed of nine genera followed by Apocynaceae with four genera and Connaraceae with three genera (S1). In terms of a number of species, the richest genera are Connarus (six species), Spatholobus (six species) and Strychnos (five species). For each study site, Sungai Papan has the highest recorded species (39 species) followed by Teluk Gopal (38 species) and Sungai Kejar (37 species). Sungai Papan and Teluk Gopal also have the highest diversity indices compared with others (Table 2). There was overlap in the confidence intervals of the rarefied and extrapolated species richness curves of all the sites. Sungai Papan and Teluk Gopal had the highest species richness which was not significantly different (Figure 2). 
Table 2. Diversity indices of liana species in the study sites.

\begin{tabular}{lccccc}
\hline Diversity Indices & $\begin{array}{c}\text { Sungai } \\
\text { Kejar }\end{array}$ & $\begin{array}{c}\text { Sungai } \\
\text { Papan }\end{array}$ & $\begin{array}{c}\text { Sungai } \\
\text { Papan 2 }\end{array}$ & $\begin{array}{c}\text { Teluk } \\
\text { Gopal }\end{array}$ & $\begin{array}{c}\text { Sungai } \\
\text { Kooi }\end{array}$ \\
\hline Simpson Index & 0.9667 & 0.9671 & 0.9603 & 0.9698 & 0.9615 \\
Shannon Index & 3.493 & 3.526 & 3.297 & 3.571 & 3.326 \\
Evenness Index & 0.889 & 0.872 & 0.901 & 0.912 & 0.898 \\
Fisher alpha & 22.5 & 24.72 & 16.69 & 20.49 & 15.27 \\
Rarefied and extrapolated species richness & 36 & 39 & 29 & 39 & 30 \\
\hline
\end{tabular}

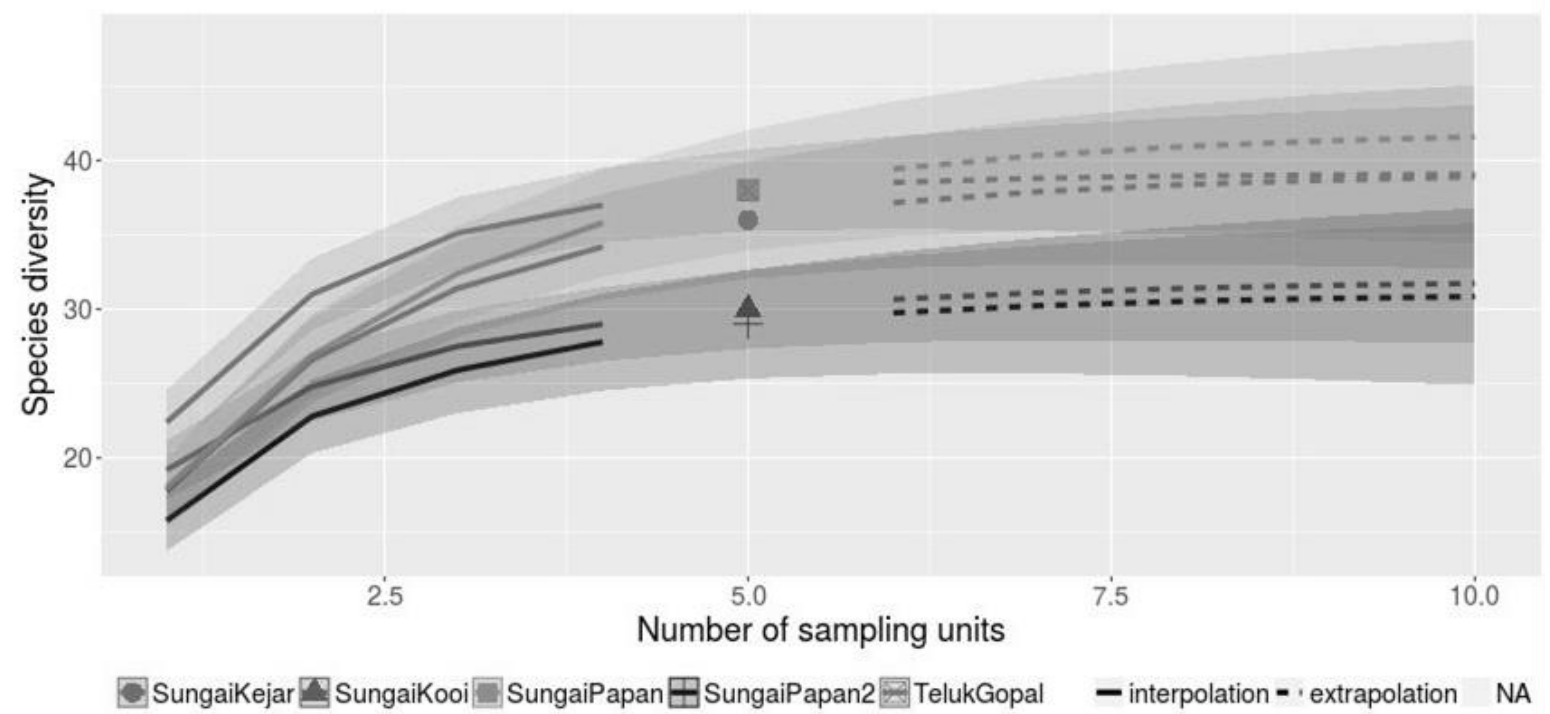

Figure 2. Incidence based rarefaction and extrapolation curves for species richness (including confidence intervals) of liana species. Solid lines represent rarefaction curves while dashed lines represent extrapolation curves. Each dot stands for the estimated species richness. The shadow of each curve represents the confidence interval.

Analysis of species similarity displays the cluster analysis of liana community in different sites (Figure 3). The highest value was indicated between Sungai Papan and Teluk Gopal (0.50) which implies the highest species similarity in both study sites, followed by Sungai Kejar and Sungai Papan 2 (0.37). Whilst, the comparison between Node 1 (consisting of Teluk Gopal and Sungai Papan) and Sungai Kooi read the second highest at 0.34. Notwithstanding, the lowest value was denoted between Node 2 (consisting of Sungai Kooi, Teluk Gopal and Sungai Papan) and Node 3 (consisting of Sungai Papan 2 and Sungai Kejar) at 0.36, which suggests the lowest species similarity recorded between them.

\section{Diversity, Richness and Similarities of Tree Species Between Study Sites}

Results showed that 221 trees species belonging to 48 families were identified in all the sites (S2). The families with the high number of species include Annonaceae (23 species, 16 genera) followed by Euphorbiaceae (22 species, 12 genera) and Meliaceae (18 species, eight genera). The richest genus was Syzygium (11 species) followed by Dacryodes (seven species) and Shorea (six species). Sungai Kejar was observed to have the highest tree species richness and diversity while Sungai Kooi had the lowest (Table 3). However, all the study sites had the same even distribution of tree species. 


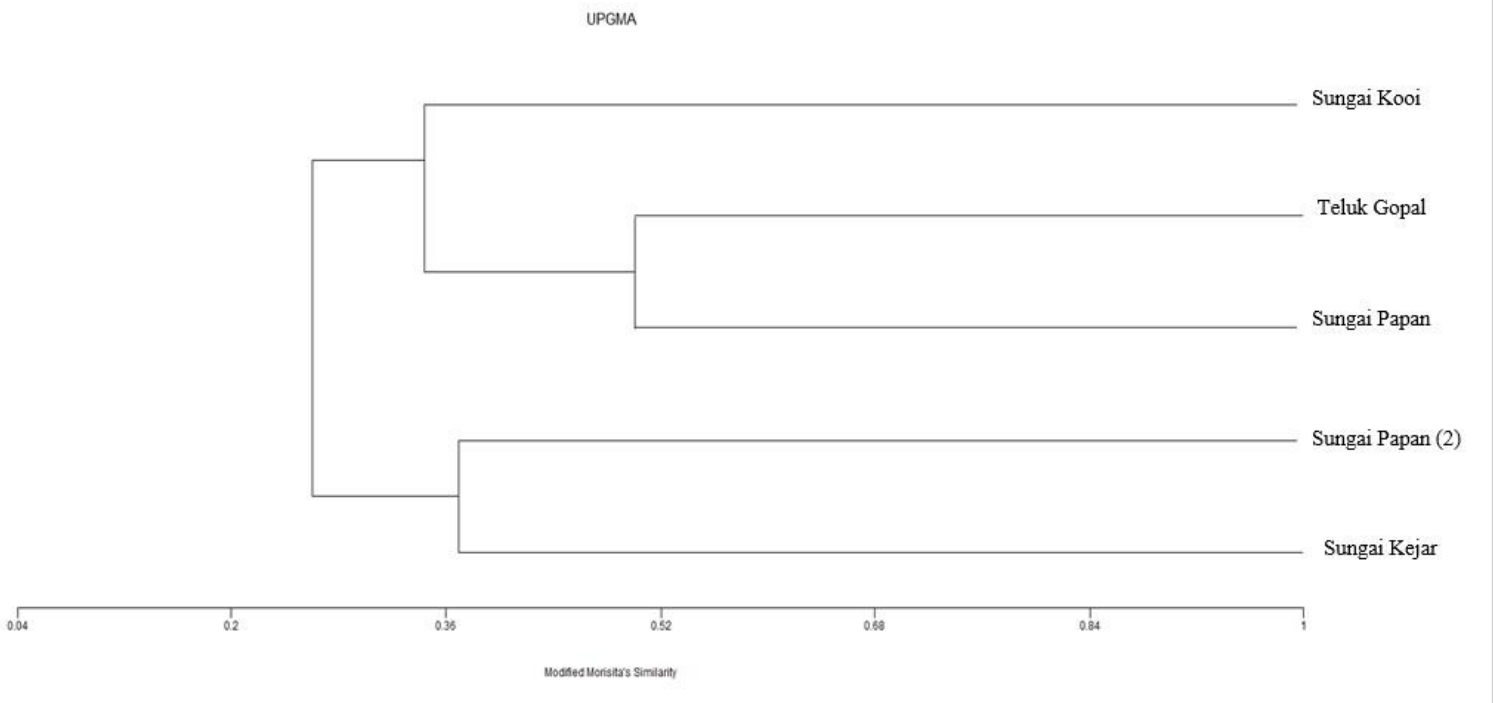

Figure 3. Tree diagram of clustering method (UPGMA) on liana community in the study sites of Royal Belum State Park.

The rarefied and extrapolated analysis of species richness showed an overlap in the confidence intervals of all the sites which indicated no significant difference between them (Figure 4). However, rarefied-extrapolated curves did not reach asymptote for all the sites, meaning that the sampling size was not adequate. The cluster analysis revealed the similarity of censuses trees species (Figure 5). The highest value was observed between Sungai Kooi and Teluk Gopal (0.27) followed by Sungai Papan and Sungai Papan 2 (0.23). Whilst, the comparison between Node 2 (consisting of Teluk Gopal and Sungai Kooi) and Node 1 (consisting of Sungai Papan and Sungai Papan 2) recorded the second highest at 0.20 .
Notwithstanding, the lowest value was denoted between Sungai Kejar and Node 3 (consisting of four study sites) at 0.14 , which suggests the lowest species similarity recorded between them.

\section{IUCN Conservation Status of Lianas and Trees}

The assessment of the IUCN status of the lianas showed six species as Least Concern while the others have Deficient Data (Table 4). However, the IUCN conservation status of the trees showed that two are Critically Endangered, three are Endangered, 11 are Vulnerable, eight are Near Threatened, 31 are Least Concern while the remaining 166 are Data Deficient (Table 5).

Table 3. Diversity indices of tree species in the study sites.

\begin{tabular}{lccccc}
\hline Diversity Indices & $\begin{array}{c}\text { Sungai } \\
\text { Kejar }\end{array}$ & $\begin{array}{c}\text { Sungai } \\
\text { Papan }\end{array}$ & $\begin{array}{c}\text { Sungai } \\
\text { Papan 2 }\end{array}$ & $\begin{array}{c}\text { Teluk } \\
\text { Gopal }\end{array}$ & $\begin{array}{c}\text { Sungai } \\
\text { Kooi }\end{array}$ \\
\hline Simpson Index & 0.9809 & 0.9819 & 0.9788 & 0.9816 & 0.9730 \\
Shannon Index & 4.089 & 4.088 & 3.95 & 4.072 & 3.754 \\
Evenness Index & 0.865 & 0.904 & 0.880 & 0.903 & 0.821 \\
Fisher alpha & 49.13 & 42.59 & 37.86 & 42.99 & 33.14 \\
Rarefied and extrapolated species richness & 68 & 65 & 58 & 64 & 50 \\
\hline
\end{tabular}




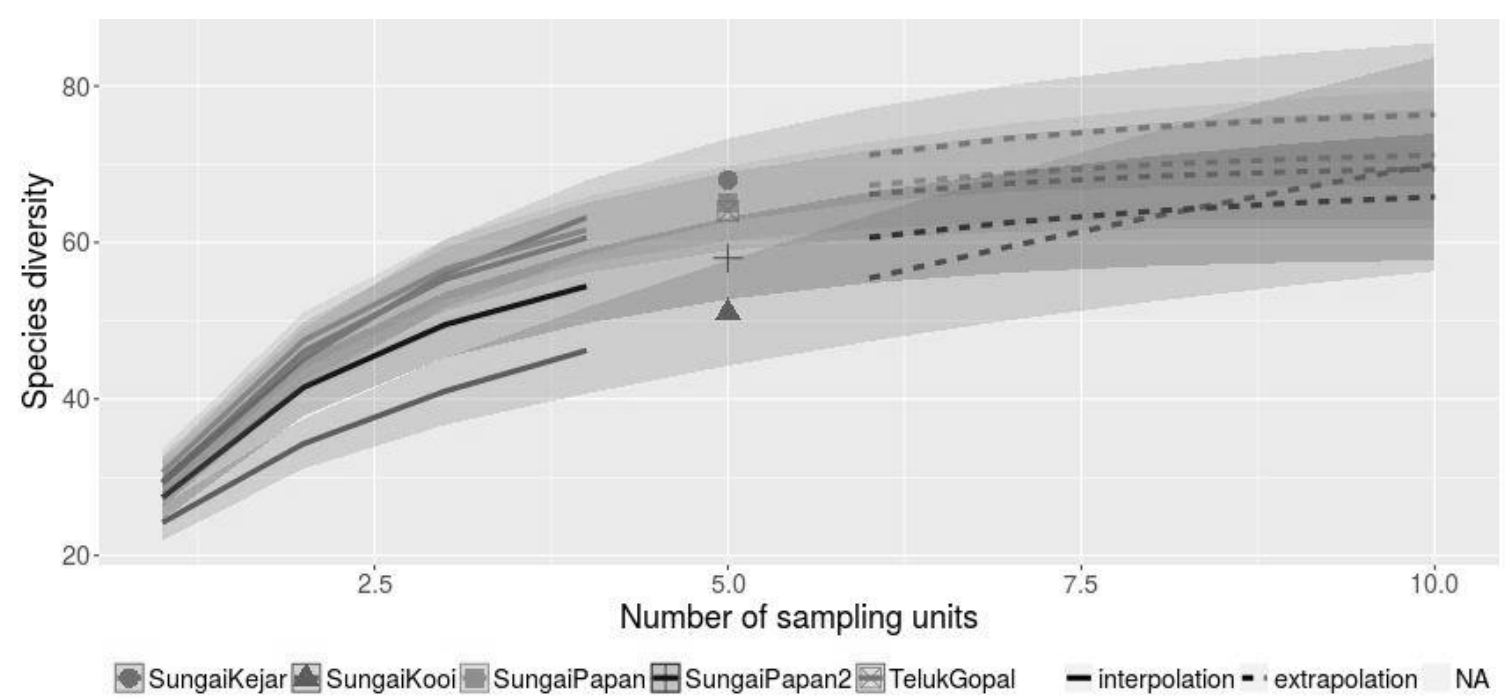

Figure 4. Incidence based rarefaction and extrapolation curves for species richness (including confidence intervals) of tree species. Solid lines represent rarefaction curves while dashed lines represent extrapolation curves. Each dot stands for the estimated species richness. The shadow of each curve represents the confidence interval.

UPGMA
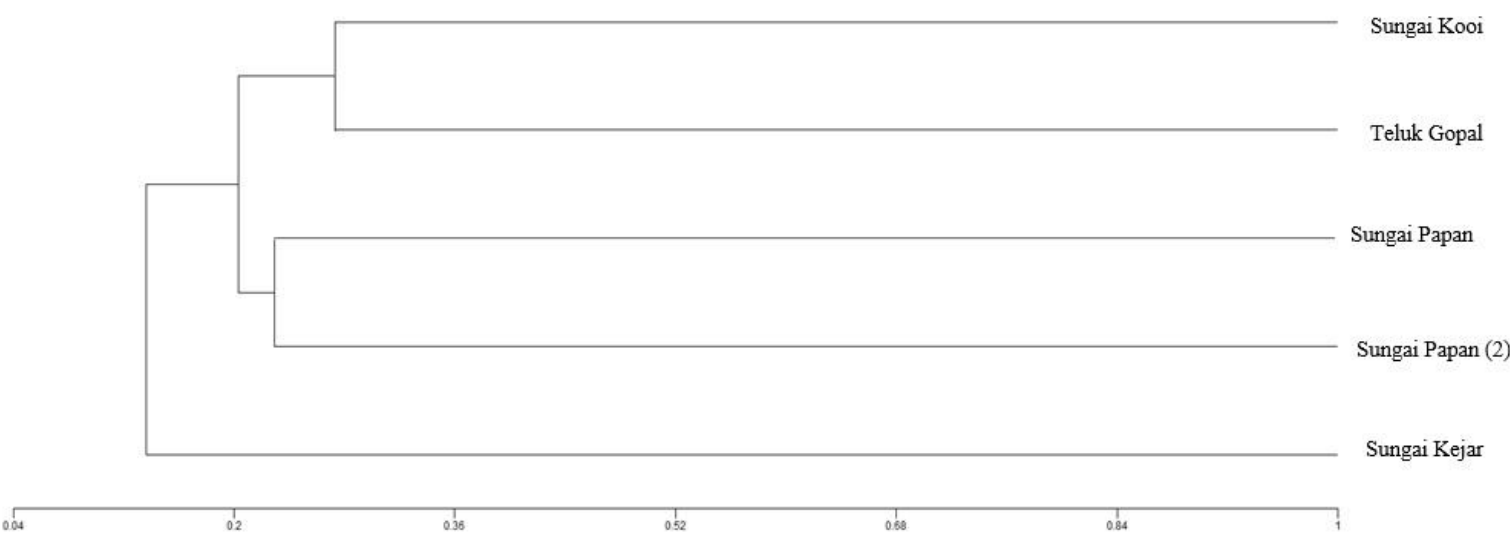

Figure 5. Tree diagram of clustering method (UPGMA) on liana community in the study sites of Royal Belum State Park.

Table 4. IUCN conservation status of lianas in the study sites.

\begin{tabular}{lcl}
\hline IUCN Red List Status & Number of Species & Name of Species \\
\hline Extinct (EX) & 0 & Nil \\
Extinct in the Wild (EW) & 0 & Nil \\
Regionally Extinct (RE) & 0 & Nil \\
Critically Endangered (CR) & 0 & Nil \\
Endangered (EN) & 0 & Nil \\
Vulnerable (VU) & 0 & Nil \\
Near Threatened (NT) & 0 & Nil \\
Least Concern (LC) & 6 & Bauhinia acuminata, Spatholobus gyrocarpus, \\
& & Gnetum gnemonoides, Gnetum latifolium, Gnetum \\
Data Deficient (DD) & & macrostachyum, Gnetum microcarpum \\
\hline
\end{tabular}


Table 5. IUCN conservation status of trees in the study sites.

\begin{tabular}{|c|c|c|}
\hline IUCN Red List Status & Number of Species & Name of Species \\
\hline Extinct (EX) & 0 & 0 \\
\hline Extinct in the Wild (EW) & 0 & 0 \\
\hline Regionally Extinct (RE) & 0 & 0 \\
\hline Critically Endangered (CR) & 2 & Dipterocarpus kunstleri, Shorea lepidota \\
\hline Endangered (EN) & 3 & $\begin{array}{l}\text { Parashorea densiflora, Shorea parvifolia, Shorea } \\
\text { pauciflora }\end{array}$ \\
\hline Vulnerable (VU) & 11 & $\begin{array}{l}\text { Dipterocarpus gracilis, Hopea sangal, Hopea } \\
\text { sublanceolata, Parashorea stellate, Vatica pauciflora, } \\
\text { Beilschmiedia dictyoneura, Endocomia canarioides, } \\
\text { Horsfieldia polyspherula, Horsfieldia sucosa, Pentace } \\
\text { perakensis, Schoutenia kunstleri }\end{array}$ \\
\hline Near Threatened (NT) & 8 & $\begin{array}{l}\text { Shorea leprosula, Castanopsis curtisii, Aglaia } \\
\text { leucophylla, Aglaia oligophylla, Aglaia palembanica, } \\
\text { Aglaia rubiginosa, Aglaia squamulosa, Palaquium } \\
\text { hexandrum }\end{array}$ \\
\hline Least Concern (LC) & 31 & $\begin{array}{l}\text { Anisophyllea corneri, Alphonsea maingayi, Endiandra } \\
\text { maingayi, Tabernaemontana corymbosa, Canarium } \\
\text { littorale, Canarium patentinervium, Dacryodes laxa, } \\
\text { Dacryodes costata, Dacryodes puberula, Dacryodes } \\
\text { rostrata, Dacryodes rugosa, Santiria apiculata, } \\
\text { Santiria tomentosa, Santiria laevigata, Shorea } \\
\text { multiflora, Diospyros ridleyi, Diospyros singaporensis, } \\
\text { Paracroton pendulus, Ormosia macrodisca, Irvingia } \\
\text { malayana, Beilschmiedia insignis, Chisocheton } \\
\text { tomentosus, Sandoricum koetjape, Xylocarpus } \\
\text { moluccensis, Knema conferta, Myristica iners, Prunus } \\
\text { arborea, Prunus grisea, Payena maingayi, Celtis } \\
\text { rigescens, Rinorea horneri }\end{array}$ \\
\hline Data Deficient (DD) & 1 & Others \\
\hline
\end{tabular}

\section{DISCUSSION}

The composition, abundance and diversity of lianas in some tropical forests has been directly influenced by the intensity of human disturbances (Schnitzer \& Bongers, 2011; AddoFordjour \& Rahmad, 2015). In these disturbed tropical forests, lianas became over-populated and exerted limiting effects on neighbouring plants, especially trees (Paul \& Yavitt, 2011). This could mean that Sungai Papan and Teluk Gopak have undergone little human disturbances over the years. Favourable environmental conditions such as increased $\mathrm{CO}_{2}$ level, sunlight availability and enough space for growth have been reported as promoters of liana diversity and abundance in disturbed tropical forests (Gerwing $\&$ Farias, 2000). The presence of tree species of
Annonaceae, Euphorbiaceae and Meliaceae could mean that these dominated plant families and genera are typical trees of tropical rain forests (Francoso et al., 2016). The variations observed in the spread of these trees in all the sites in such a way that the abundant species in one site while less-abundant in the others and vice versa might just be as a result of delimitation in the geographical areas and time, not necessarily by physiological differences (Oliveira \& Amaral, 2004).

This inventory and diversity assessments of trees in these study sites have been able to provide the understanding of the current richness status of the trees which could serve as a guide for driving the future conservation plans of these 
forests (Jayakumar et al., 2011; Francoso et al., 2016). Researches have shown that the abundance of lianas in tropical forests usually reduced trees regeneration and interfered with ecosystem processes that tend to enhance trees richness and diversity (Garcia et al., 2018). This means that abundance of lianas will directly reduce the abundance and diversity of trees in a forest community. Lianas are able to achieve this by competing with trees for water, soil nutrients and light (Perez-Salicrup et al., 2001; Schnitzer et al., 2005). The high tree species composition, richness and diversity recorded in our study revealed that these study areas have not been so much infested by liana species. The most important indicator of disturbances in a forest ecosystem is the high density of lianas compared to trees in such forests (Villagra et al., 2013; Oliveira et al., 2014). Invariably, most forests inside the Royal Belum State Park have not experienced a high level of disturbance over the years. According to the IUCN conservation status of the lianas and trees, it can be deduced that the most important tree species in this forest which are categorized as Endangered and Critically Endangered are Parashorea densiflora, Shorea parvifolia, Shorea pauciflora Dipterocarpus kunstleri and Shorea lepidota. None of the lianas can be described as important species for conservation. Also, lack of adequate data and assessment of the conservation status of most of these plants should be a serious concern to conservationists.

\section{CONCLUSION}

Royal Belum State Park encapsulates a mesmerizing diversity of lianas and trees together with the hospitable environmental condition. The similarity of species is considerably low suggesting high species richness. Both plant habits are important forest structure and are beneficial to animals, especially for protection. Therefore, it is reasonable to ensure the conservation of these forest resources. It is hereby suggested that the forest management should pay close attention to the most important tree species highlighted in this study, which stand the risk of going into extinction if not conserved immediately.

\section{ACKNOWLEDGEMENTS}

We are wholeheartedly grateful to Perak State Forestry Department, Pulau Banding Research Foundation for providing the facilities and rangers during the study duration and USM research Grant 1001/PBIOLOGI/811330 for the financial support.

\section{REFERENCES}

Addo-Fordjour, P., Anning, A.K., Atakora, E.A. \& Agyei, P.S. (2008). Diversity and distribution of climbing plants in a semi-deciduous rain forest, KNUST Botanic Garden, Ghana. International Journal of Botany, 4: 186-195.

Addo-Fordjour, P. \& Rahmad, Z.B. (2015). Liana community assemblages in relation to human disturbance in a tropical forest in Ghana: implications for conservation. International Journal of Biodiversity Science, Ecosystem Services \& Management, 10(4): 11-59.

Addo-Fordjour, P., Rahmad, Z.B. \& Burham, R.J. (2016). Intercontinental comparison of liana community assemblages in tropical forests of Ghana and Malaysia. Journal of Plant Ecology, 10(6): 883-894.

Chao, A., Ma, K.H. \& Hsieh, T.C. (2016). iNEXT (iNterpolation and EXTrapolation) Online: Software for Interpolation and Extrapolation of Species Diversity. Program and User's Guide. http://chao.stat.nthu.edu.tw/wordpress/software_d ownload/. Downloaded on 7 May 2018.

Dixon, R.K., Brwon, R.A., Houghton, R.A., Solomon, A.M., Trexler, M.C. \& Wisniewski, J. (1994). Carbon pools and flux of global forest ecosystems. Science, 263: 185-190.

Francoso, R.D., Haidar, R.F. \& Machado, R.B. (2016). Tree species of South America central savanna: endemism, marginal areas and the relationship with other biomes. Acta Botanica Brasilica, 30(1): 78-86.

Garcia, L., Maria, M., Martinez, I., Laura, M., Felipe, N.A.P., Jennifer, S.S., Stefan, A. \& Edwards, D. (2018). Lianas reduce community-level canopy tree reproduction in a Panamanian forest. The Journal of Ecology, 106(2): 737-746.

Gerwing, J.J. \& Farias, D.L. (2000). Integrating liana abundance and forest stature into an estimate of total aboveground biomass for an eastern Amazonian forest. Journal of Tropical Ecology, 16: 327-335. 
Ingwell, L.L., Wright, S.J., Becklund, K.K., Hubbell, S.P. \& Schnitzer, S.A. (2010). The impact of lianas on 10 years of tree growth and mortality on Barro Colorado Island, Panama. Journal of Ecology, 98: 879-887.

Jayakumar, S., Kim, S.S. \& Heo, J. (2011). Floristic inventory and diversity assessment - a critical review. National Academy of Ecology and Environmental Sciences, 1: 151-168.

Khairil, W.A., Suhani, I. \& Hairani, M.N. (2012). Belum-Temengor Forest Complex: An ecotourism perspective. In Hurzaid, A., Bakar, M.A., Sharma, D., Nasir, N., Sharma, R., Aznan, A.R., \& Jaafar, I. (Eds.), Proceedings of the $2^{\text {nd }}$ Temengor Scientific Expedition, August 22-25. Selangor: Pulau Banding Foundation. Pp 53-60.

Kiew, R., Chung, R.C.K., Saw, L.G., Soepadmo, E. \& Boyce, P.C. (Eds.). (2010). Flora of Peninsular Malaysia, Series II: Seed Plants, Volume 1. Malaysia: Forest Research Institute Malaysia, Kepong.

Kiew, R., Chung, R.C.K., Saw, L.G., Soepadmo, E. \& Boyce, P.C. (Eds.). (2011). Flora of Peninsular Malaysia, Series II: Seed Plants, Volume 2. Malaysia: Forest Research Institute Malaysia, Kepong.

Kiew, R., Chung, R.C.K., Saw, L.G. \& Soepadmo, E. (Eds.). (2012). Flora of Peninsular Malaysia, Series II: Seed Plants, Volume 3. Malaysia: Forest Research Institute Malaysia, Kepong.

Krebs, C.J. (1989). Ecological methodology. New York: Harper \& Row.

Ng, F.S.P. (1978). Tree flora of Malaya: A manual for foresters, Volume 3. Malaysia: Longman.

Ng, F.S.P. (1989). Tree flora of Malaya: A manual for foresters, Volume 4. Malaysia: Longman.

Oliveira, A.N. \& Amaral, I.L. (2004). Floristica efitossociologia de uma floresta de vertente na Amazonia Central, Amazonas, Brasil. Acta Amazonica, 34(1): 21-34.

Oliveira, E.A., Marimon, B.S., Feldpausch, T.R., Colli, G.R., Marimon-Junior, B.H., Lloyd, J., Lenza, E., Maracahipes, L., Oliveira-Santos, C. \& Philips, O.L. (2014). Diversity, abundance and distribution of lianas of the Cerrado Amazonian forest transition. Plant Ecology Diversity, 7(1-2): 231-240.

Paul, G.S. \& Yavitt, J.B. (2011). Tropical vine growth and the effects on forest succession: a review of the ecology and management of tropical climbing plants. Botanical Review, 77: 11-30.
Pérez-Salicrup, D.R. (2001). Effect of liana cutting on tree regeneration in a liana forest in Amazonian Bolivia. Ecology, 82: 389-396.

Perez-Salicrup, D.R., Sork, V.L. \& Putz, F.E. (2001). Lianas and trees in a liana forest of Amazonian Bolivia. Biotropica, 33: 34-47.

Potter, C.S. (1999). Terrestrial biomass and the effects of deforestation on the global carbon cycle. Bioscience, 49: 769-778.

Putz, F.E. (2012). Vine ecology. Ecology Information, 24: $1-10$.

Rahmad, Z.B. \& Akomolafe, G.F. (2018). Distribution, diversity and abundance of ferns in a tropical university campus. Pertanika Journal of Tropical Agricultural Science, 41(4): 1875-1887.

Romesburg, H.C. (1984). Cluster analysis for researchers. Belmont, California: Lifetime Learning Publications.

Schnitzer, S.A. \& Bongers, F. (2011). Increasing liana abundance and biomass in tropical forests: emerging patterns and putative mechanisms. Ecology Letter, 14: 397-406.

Schnitzer, S.A., Dalling, J.W. \& Carson, W.P. (2000). The impact of lianas on tree regeneration in tropical forest canopy gaps: evidence for an alternative pathway of gap-phase regeneration. Journal of Ecology, 88: 655-666.

Schnitzer, S.A., Kuzee, M.E. \& Bongers, F. (2005). Disentangling above and below-ground competition between lianas and trees in a tropical forest. Journal of Ecology, 93: 1115-1125.

Tobin, I., Bony, S. \& Roca, R. (2012). Observational evidence for relationships between the degree of aggregation of deep convection, water vapor, surface fluxes, and radiation. Journal of Climate, 25: 6885-6904.

Villagra, B.L.P., Gomes, E.P.C., Burnham, R.J. \& Neto, S.R. (2013). Diversity and abundance of climbers from the Atlantic Forest, Southeastern Brazil. Biodiversity and Conservation, 22(11): 2505-2517.

Whitmore, T.C. (1983a). Tree flora of Malaya: a manual for foresters, Volume 1. Malaysia: Longman.

Whitmore, T.C. (1983b). Tree flora of Malaya: a manual for foresters, Volume 2. Malaysia: Longman. 